\title{
THE FAT, PROTEIN AND NUCLEIC ACID CONTENT OF THE LIVER IN MALNOURISHED HUMAN INFANTS
}

\author{
BY J. C. WATERLOW AND T. WEISZ \\ (From the Tropical Metabolism Research Unit, Medical Research Council, and Department of \\ Physiology, University College of the West Indies, Jamaica, B. W. I.)
}

(Submitted for publication September 9, 1955 ; accepted November 23, 1955)

In parts of the world where milk is in short supply babies after weaning are commonly put on a diet consisting mainly of carbohydrate. One result of this regimen is the development of a very fatty liver. The clinical and pathological features of these cases have been reviewed by Gillman and Gillman (1), Waterlow (2), and Trowell, Davies, and Dean (3). From several points of view it is of interest to know something about the composition of the fatty livers found in these cases. Earlier work suggested to one of us that the degree of fatty infiltration determined the severity of the disease, the response to treatment, and the likelihood of death (Waterlow, [2]). In the last few years, however, we have been able to measure the fat content of biopsy samples of the liver in a much larger series of cases. The results do not support the original conclusion, since no correlation has been found between the amount of fat in the liver and the clinical condition of the child (Waterlow [4]).

Microscopically, in most of the liver cells in these cases there is only a thin rim of cytoplasm surrounding a large fat globule. It seems possible that this may not be simply the result of distension of the cell by fat, as has usually been assumed; there may have been an actual loss of cytoplasm as well.

It is well known that when rats are starved or put on a protein-free diet, in a few days they may lose up to $\mathbf{4 0}$ per cent of their total liver protein, ribonucleic acid and phospholipid (Addis, Poo and Lew [5] ; Kosterlitz [6] ; Campbell and Kosterlitz [7]; Munro and Naismith [8]; Thomson, Heagy, Hutchison, and Davidson [9]). In none of these experiments, however, did the rats develop fatty livers. The fatty infiltration of the liver that is produced in rats by dietary means seems not to be accompanied by such large losses of liver protein. Presumably this is because the diets which most effectively produce fatty livers in rats, although de- ficient in lipotropic factors, are not necessarily very low in protein. In man, however, the case is different. The cause of the fatty liver in kwashiorkor is still unknown, but it is probably not simply a deficiency of lipotropic factors such as choline and methionine (Waterlow [2]). There is nearly always a history of a very low protein intake. That being so, it seems logical to suppose that there may be two processes going on side by side in these livers-accumulation of excess fat, and depletion of protein and other cytoplasmic constituents. The measurements described in this paper were undertaken to test this hypothesis.

Since in the living subject we cannot measure the weight of the liver and hence the total liver protein, it is necessary to relate all measurements to a fixed standard of reference. This problem of a standard has been discussed by Thomson, Heagy, Hutchison, and Davidson (9). They found, in agreement with the earlier work of Kosterlitz and Campbell (7), that in the adult rat deoxyribosenucleic acid (DNA) can be used as a standard of reference, since the total amount of DNA in the liver remained constant under a wide variety of dietary conditions. They also showed that under the conditions of their experiments there was no change in the average amount of DNA per cell. Thus changes in other constituents, when referred to DNA, could be interpreted as changes in the composition of the average liver cell.

Most of this experimental work was done on fully grown rats, and the conclusions cannot be applied without scrutiny to our cases, who were infants. The total DNA content of the liver is certainly not constant in the growing organism, nor does the average amount of DNA per nucleus remain unchanged. These points will be considered in more detail in the discussion. Although we recognize that DNA may not be a completely valid standard of reference, we have nevertheless 
found it useful, as the best available approximation, for giving some insight into the changes occurring in the livers of our cases.

In this paper we report the results of measurements, before and after treatment, of the protein, DNA and ribosenucleic acid (RNA) content of the liver in a group of malnourished infants with fatty livers. Measurements of the activity of a number of liver enzymes have also been made at various times in the course of this work. Some of these results have already been reported (Waterlow $[10,11]$; Waterlow and Patrick [12]).

\section{METHODS}

Preparation of tissues. Liver biopsy was done under local anesthesia ( 2 per cent $w / v$ Procaine) by the transpleural route of Iversen and Roholm (13). The tissue was transferred to a piece of filter-paper moistened with saline, and put on ice in a stoppered tube. This procedure is open to criticism, since it may cause some alteration in water content. It was adopted in order to preserve the tissue as far as possible undamaged for enzyme assays. For measurement of water content by the method of Billing, Conlon, Hein, and Schiff (14) it is necessary to have a micro-balance by the bedside, which was not feasible for us. There was inevitably some delay before measurements could be begun, and the specimen usually remained on ice for about $1 / 2$ an hour. Samples weighing 1 to $2 \mathrm{mg}$. were taken for enzyme assays. Another sample was fixed in Bouin's fluid for histological examination. A third fragment, weighing 1 to $2 \mathrm{mg}$, was weighed on a quartz fibre torsion balance, and then dried over phosphorus pentoxide. The water content was calculated by difference.

Fat was estimated by extraction of the dried tissue overnight with hot ethyl ether in a micro-Soxhlet apparatus. The tissue was dried and weighed, and the fat content calculated by difference. In unpublished experiments it was found that this simple method of extraction removes all the excess neutral fat but leaves behind lipid amounting to some 2 per cent of the fresh weight. This error, however, was not important, since we are dealing with livers containing a very great excess of neutral fat (Table II).

Nucleic acids were extracted from the dry fat-free tissue by the method of Schneider (15). The specimen was homogenized in ice-cold 5 per cent $w / v$ trichloracetic acid (TCA), in a small glass homogenizer constructed as described by Steele, Sfortunato, and Ottolenghi (16). The homogenate was decanted into a tared tube, centrifuged, and the precipitate washed twice with cold 5 per cent TCA to remove acid-soluble nucleotides. The residue was then extracted with about $40 \mathrm{cu}$. mm. of 5 per cent TCA at $90^{\circ} \mathrm{C}$. for 15 minutes. The exact volume of the extract was determined by weighing.

Total nucleic acids in the extract were measured spectrophotometrically by their absorption at $263 \mathrm{~m} \mu$. For this estimation $7 \mathrm{cu}$. $\mathrm{mm}$. of extract were added to $\mathbf{1 7 0}$ cu. mm. of water. At this dilution the TCA blank has an optical density of only 0.02 , whereas that of the samples was between 0.3 and 0.6. These measurements were made in a Unicam SP 500 spectrophotometer adapted for micro-cuvettes.

DNA was measured by the indole reaction of Ceriotti (17). Seven cu. $\mathrm{mm}$. of extract were added to $170 \mathrm{cu} . \mathrm{mm}$. of indole reagent. This reaction is extremely sensitive; measurements can be made with ease on extracts containing $0.1 \mu \mathrm{g}$. or less of DNA-phosphorus per aliquot of $7 \mathrm{cu}$. mm. All measurements were made in duplicate. In 50 consecutive estimations by the indole method the mean difference between duplicates was 4.7 per cent (S.E. \pm 4.76$)$. RNA was calculated by difference from these two measurements.

It was found that perchloric acid, which has been recommended by Ogur and Rosen (18) for the extraction of nucleic acids, decreased the intensity of the indole color, particularly if the extracts were left for any length of time in the refrigerator, whereas in TCA the nucleotides seem to be quite stable. It was for this reason that TCA was chosen as the extracting medium, although it has an appreciable absorption in the ultra-violet.

Calculation. In each set of indole measurements a standard was included made from semi-purified human DNA. This was prepared from post-mortem tissue by the method of Brues, Tracy, and Cohn (19), and had an optical density at $263 \mathrm{~m} \mu$. of 0.279 per $\mu \mathrm{g}$. phosphorus per $\mathrm{ml}$. (molar extinction coefficient $=8,950$ ). This factor was used to calculate the contribution of the DNA, as measured by the indole reaction, to the ultra-violet absorption of the mixed nucleic acids. The total absorption at $263 \mathrm{~m} \mu$. minus the absorption due to $\mathrm{DNA}=$ absorption due to RNA. From this remainder the RNA concentration was calculated, using a factor derived from human RNA prepared by the same method (Brues, Tracy. and Cohn [19]). The RNA standard had an optical density at $263 \mathrm{~m} \mu$. of 0.303 per $\mu \mathrm{g}$. phosphorus per ml. (molar extinction coefficient $=9,400$ ). Results for both DNA and RNA are expressed in terms of nucleic acid phosphorus.

Measurement of RNA by difference has undoubted disadvantages, since errors tend to be magnified. The method was chosen, however, because it was found that the orcinol method of Mejbaum (20), as used by Schneider (15) and many subsequent workers, was insufficiently specific. Human liver contains large quantities of glycogen (see below), much of which is not removed by washing with cold TCA. The glucose that is produced on hydrolysis with hot TCA interferes in the orcinol reaction. The color produced by glucose has an absorption maximum at $540 \mathrm{~m} \mu$. (Drury [21]), whereas with ribose the maximum is at 660 to $670 \mathrm{~m} \mu$. However, even when corrections were made, based on readings at both wave-lengths, we were not able to get satisfactorily reproducible results.

Protein nitrogen was measured in the residue after extraction of the nucleic acids. The residue was washed into a thick-walled pyrex tube, $120 \mathrm{cu}$. mm. of 50 per 
cent (v/v) $\mathrm{H}_{2} \mathrm{SO}_{4}$ were added containing 1 per cent $(\mathrm{w} / \mathrm{v}) \mathrm{CuSO}_{4}$ and 1 per cent $(\mathrm{w} / \mathrm{v}) \mathrm{SeO}_{2}$, and the tube was put in the oven at $100^{\circ}$ until excess water had been evaporated off. The tubes were then heated in a brass block on an electric hot-plate at about $300^{\circ}$ for at least 8 hours. After cooling, $1 \mathrm{ml}$. of water was added, and aliquots were Nesslerized by the method of Johnson (22) to give a final volume of $3.5 \mathrm{ml}$.

Glycogen was estimated in a few specimens by the method described by Patrick (23). This could not be done as a routine, because enough tissue was usually not available.

Sampling error. Although the pathological process in these cases-fatty infiltration-is relatively uniform, the liver is not an entirely homogeneous tissue. Therefore in such small fragments, which include only a few lobules, a large sampling error is to be expected. In preliminary studies on enzymes, duplicate estimations made on separate pieces of biopsy tissue agreed surprisingly well (Waterlow [10]). The variation in nucleic acid content seems to be larger. In two experiments six pieces of about $1 \mathrm{mg}$. fat-free dry weight were taken from specimens of liver obtained at necropsy. The results were as follows :

\section{DNAP, $\mu$ g. per mg. N.}

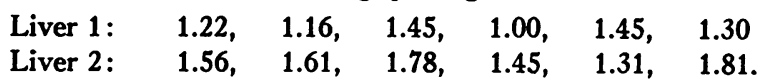

The variability is large, and it is to be expected that significant differences in nucleic acid content can only be established between groups of observations. A single measurement has little meaning when made on such a small amount of tissue.

TABLE I

Clinical features of cases investigated *

\begin{tabular}{|c|c|c|}
\hline & & Range \\
\hline $\begin{array}{l}\text { Number of cases } \\
\text { Mean age, months } \\
\text { Mean weight deficit, per cent } \dagger \\
\text { Mean liver enlargement, cm. } \ddagger \\
\text { Number with edema: Severe }\end{array}$ & $\begin{array}{c}12 \\
12.25 \\
44 \pm 7.3 \\
4 \pm 1.3 \\
7 \\
3\end{array}$ & $\begin{array}{c}(6-19) \\
(35-54) \\
(2-7)\end{array}$ \\
\hline $\begin{array}{l}\text { Number with dermatosis } \\
\text { Number with mucosal lesions } \\
\text { Number with dyspigmented hair } \\
\text { Mean serum total protein, } \\
\text { g. per } 100 \text { ml. }\end{array}$ & $\begin{array}{l}3 \\
4 \\
5 \\
6\end{array}$ & \\
\hline $\begin{array}{l}\text { On admission } \\
\text { On discharge§ } \\
\text { Mean serum choline esterase, }\end{array}$ & $\begin{array}{l}4.4 \pm 0.84 \\
6.85 \pm 0.35\end{array}$ & $\begin{array}{l}(3.2-5.8) \\
(6.3-7.4)\end{array}$ \\
\hline $\begin{array}{l}\text { Mn admission } \\
\text { On discharge }\end{array}$ & $\begin{array}{l}0.23 \pm 0.115 \\
0.68 \pm 0.07\end{array}$ & $\begin{array}{l}(0.08-0.50) \\
(0.61-0.82)\end{array}$ \\
\hline $\begin{array}{l}\text { Mean weight gain on treatment, } \\
\text { kg. per week }\end{array}$ & $0.18 \pm 0.06$ & $(0.09-0.32)$ \\
\hline
\end{tabular}

* Mean \pm standard deviation.

$\dagger$ Deficit of weight below standard weight for age, as given by Holt and Howland (39). Weight measured after the loss of edema.

$\ddagger$ Distance of liver edge below costal margin.

Excluding one case discharged before clinical recovery was complete.

\section{CLINICAL DATA}

The results reported here were obtained on 12 babies with fatty livers from whom more than one biopsy was available, taken before and after treatment. These were the only criteria for inclusion in the group. By a fatty liver is meant one in which fat forms more than 20 per cent of the fresh weight. Many observations were made on other miscellaneous cases, but they do not form a sufficiently homogeneous series for any conclusions to be drawn.

The general characteristics of this group are summarized in Table I. The picture is typical of kwashiorkor as it is seen in Jamaica (Waterlow [2]; Jelliffe, Bras, and Stuart [24]). All the babies were grossly underweight, yet most of them still retained some subcutaneous fat, often in considerable amounts; thus the reduction in tissue mass was probably even greater than appears from the figures for body weight. Clinically, a striking feature of these cases is the very severe loss of muscle substance. The buttocks, for instance, seem to consist of nothing but a fold of skin. Mucosal lesions and dermatosis, which are thought to be caused by vitamin deficiencies, were usually not severe. The reductions in serum protein and choline esterase are characteristic (Waterlow [2]; Dean and Schwartz [25]).

It is impossible to give an exact estimate of the diet before admission to hospital. The downhill course starts at the time of weaning, and in the average case the condition takes two or three months to develop. During this time the baby is fed mainly on starchy paps, of which the most popular is cornmeal porridge. The maximum milk intake was probably about $1 / 4$ pint of cow's milk per day, or its equivalent as condensed milk, giving a protein intake of 4 to 5 grams a day.

On admission to hospital the babies were put for the first few days on a diluted skim-milk mixture calculated to provide about 8 grams of protein a day. It had been found previously that an intake of this order seems just to maintain the status quo, and to produce neither improvement nor deterioration (Waterlow [2]). Frequently vomiting makes it impossible to secure a higher intake, and in severe cases it may be necessary to give transfusions of plasma or whole blood. Protein hydrolysates have not been used in this hospital. The treatment of these cases has been discussed in considerable detail in a recent publication (Waterlow [4]).

The initial biochemical and hematological measurements, including measurement of prothrombin time, were made during this preliminary period on a low protein intake. The first liver biopsy was done 3 to 7 days after admission to hospital, depending on the general condition of the child. After the biopsy the strength of the milk mixture was increased by stages until an intake of 2 to 3 pints of cow's milk a day had been achieved. Supplementary foods were then given. The average duration of stay in hospital of the cases in this series was 14 weeks. Progress during the first month or even two months was frequently very slow, but in the third month the rate of weight gain became very rapid. The average 
TABLE II

Gross composition of the liver in malnourished infants *

\begin{tabular}{|c|c|c|c|c|c|c|}
\hline \multirow[b]{2}{*}{ Time of biopsy } & \multirow[b]{2}{*}{$\begin{array}{l}\text { Number of } \\
\text { specimens }\end{array}$} & \multicolumn{3}{|c|}{ Per cent of fresh weight } & \multirow{2}{*}{$\begin{array}{l}\text { Water. } \\
\text { mg. per mg. } \\
\text { fat-free } \\
\text { dry weight }\end{array}$} & \multirow{2}{*}{$\begin{array}{c}\text { Protein,t } \\
\% \text { of } \\
\text { fat-free } \\
\text { dry weight }\end{array}$} \\
\hline & & Fat & Water & $\begin{array}{c}\text { Non-fat } \\
\text { solids }\end{array}$ & & \\
\hline (1) & (2) & (3) & (4) & (5) & (6) & (7) \\
\hline On admission & 12 & $\begin{array}{c}33.8 \pm 6.5 \\
(28.6-46.5)\end{array}$ & $\begin{array}{c}51.7 \pm 5.9 \\
(39.6-58.9)\end{array}$ & $\begin{array}{l}14.3 \pm 2.15 \\
(10.9-18.1)\end{array}$ & $\begin{array}{c}3.71 \pm 0.73 \\
(2.8-5.1)\end{array}$ & $\begin{array}{c}50.0 \pm 13.1 \\
(32-75)\end{array}$ \\
\hline After 3-8 weeks & 11 & $\begin{array}{c}8.3 \pm 5.6 \\
(3.0-21.0)\end{array}$ & $\begin{array}{c}69.0 \pm 6.5 \\
(54.6-80.5)\end{array}$ & $\begin{array}{l}22.7 \pm 3.3 \\
(16.1-26.8)\end{array}$ & $\begin{array}{l}3.17 \pm 0.71 \\
(1.85-5.0)\end{array}$ & $\begin{array}{c}45.2 \pm 8.6 \\
(25-69)\end{array}$ \\
\hline After 9-24 weeks & 7 & $\begin{array}{c}3.1 \pm 2.0 \\
(0.8-7.5)\end{array}$ & $\begin{array}{c}73.7 \pm 1.7 \\
(71.5-75.7)\end{array}$ & $\begin{array}{l}23.4 \pm 1.6 \\
(21.6-27.1)\end{array}$ & $\begin{array}{l}3.36 \pm 0.55 \\
(2.66-4.83)\end{array}$ & $\begin{array}{c}52.1 \pm 14.0 \\
(34-79)\end{array}$ \\
\hline
\end{tabular}

* Mean \pm S.D.

(Range).

† Protein calculated as $\mathrm{N} \times 6.25$.

rate of weight gain over the whole period of treatment was $0.18 \mathrm{~kg}$. per week, which is about twice the normal rate for this age. Whenever possible two more biopsies were done, one during the recovery period and one just before discharge.

Ideally in a study of this kind it would be desirable to have control material from normal babies. In practice, however, this was not possible. The vast majority of our cases come from the lower economic strata: in the post-weaning period, few, if any babies of this group could be considered absolutely normal by European or American standards. Even if such babies existed in our hospital population, the pressure on bed space and the fact that liver biopsy is not a procedure entirely devoid of risk, would make it unjustifiable to admit them for investigation as a control group. On the other hand the malnourished infants described in this report were retained in hospital for as long as possible, and at the end of treatment represent the best approximation to the "normal" that we can achieve.

The same considerations apply to the cytology of the liver. The livers at the end of treatment show neither fatty infiltration nor fibrosis. They do, however, present two phenomena which might be considered abnormal: a tendency to slight cellular infiltration of the portal tracts, and an apparent increase in the number of large nuclei and binucleate cells-in other words, an increase in the degree of polyploidy. Both these phenomena have been repeatedly mentioned by workers in the tropics (Walters and Waterlow [26]; Gillman and Gillman [1]). The significance of the apparent increase in polyploidy is being investigated.

\section{RESULTS}

In human beings it is seldom that tissue is available for analysis at the instant of death. In the interval that elapses before necropsy significant chemical changes may occur. It may therefore be of interest to record some figures for the gross composition of liver specimens obtained by biopsy. Even these give only an approximate picture, since some glycogen was undoubtedly lost while the tissue was standing on ice. The results are shown in Table II.

The water content per unit fresh weight is naturally very low in the fatty livers. When related to fat-free dry weight (column 6) the water content is slightly but not significantly higher in the fatty livers than in the specimens taken after treatment. These figures, however, cannot be considered very accurate because the tissue was rinsed in saline after being removed from the biopsy needle. Subsequent measurements on both post-mortem and biopsy tissues suggest that there is a real increase in water content in the livers of these malnourished cases (to be published).

As might be expected, the protein, expressed as a percentage of the fat-free dry weight (column 7) shows no change as a result of treatment. The variability of these figures is high, probably because of varying amounts of glycogen. It was surprising to find that protein accounted for only about 50 per cent of the dry weight after ether extraction, and the question therefore arose: what is the nature of the residue? Total nucleic acids (DNA plus RNA) amount to 2 to 3 per cent. The fat extraction by ether is incomplete; some lipid is left behind, amounting to about 2 per cent of the fresh weight, or 10 per cent of the dry weight. Measurement of the ash content in two cases gave figures of 5.3 and 3.6 per cent. Finally, in 10 livers glycogen was estimated in the dried tissue; the average amount found was 21.7 per cent 
(range 10.7 to 38.2 per cent) of the fat-free dry weight. This is certainly an under-estimate of the true amount present in vivo. In a few cases samples of liver were put directly into 30 per cent $(\mathrm{w} / \mathrm{v}) \mathrm{KOH}$ at the bedside. immediately after biopsy; duplicate samples were stood on ice in the usual way. The results showed that one-third or more of the glycogen may be lost during the halfhour or so that the tissue stood on ice before being weighed and dried. If it is assumed that the true glycogen content is of the order of 30 per cent of the fat-free dry weight, then almost all the undetermined part of the residue is accounted for, and analysis of the ether extracted material would show the following composition, in round figures:

$\begin{array}{lr} & \% \\ \text { Protein } & 50 \\ \text { Lipid } & 10 \\ \text { Nucleic acids } & 2 \\ \text { Ash } & 4 \\ \text { Glycogen } & 30 \\ \text { Undetermined } & 4 \\ & 100\end{array}$

We had not expected to find such large amounts of glycogen, since the babies were fasted overnight before biopsy. There does not seem to be any consistent difference between the glycogen content of livers from malnourished and from treated cases. The severe fatty infiltration evidently has not impaired the liver's capacity to form and to store glycogen. This confirms the histological finding, that in sections stained by the periodic acid-Schiff method large amounts of glycogen are present even in cells which are grossly distended by fat globules. Very different is the picture seen in another group of Jamaican children, suffering from the disease locally called "vomiting sickness," which seems to be a toxic condition. In these children the liver is almost totally depleted of glycogen, both chemically and histologically, and the blood-sugar is reduced almost to zero (Jelliffe and Stuart [27] ; Patrick [23]).

In Table III are shown figures for the proteinnitrogen, DNA and RNA content of the liver. The cases are the same as in Tables I and II. It is evident that at the time of the first biopsythat is, before treatment-there was a severe depletion of liver protein, as judged by the low ratio of protein-N to DNA-P. The difference in N/DNA-P between the first and second biopsies is statistically significant $(P=0.01)$. That between the second and third biopsies is not significant. If the first and third biopsies are compared, it seems that these infants, at the time of their admission to hospital, had lost on the average some $\mathbf{4 0}$ per cent of their liver protein. A loss of the same order was found by Kosterlitz (6), by Munro and Naismith (8), and by Thomson, Heagy, Hutchison, and Davidson (9) in the livers of protein-starved rats.

The difference in RNA-P/DNA-P between the first and second biopsies is significant at the level of 5 per cent. The last column of Table III suggests that either the initial loss of RNA is less severe than the loss of protein, or that RNA is resynthesized more slowly.

It might be expected that the greater the degree of protein starvation the lower would be the $\mathrm{N} / \mathrm{DNA}-\mathrm{P}$ ratio, and that there might therefore be some correlation between this ratio and the general condition of the baby. This expectation has not been fulfilled, partly, no doubt, because of sampling and analytical error, but partly for other reasons which will be discussed below.

Cases that die may reasonably be regarded as the most severe unless there is some complicating factor. In six fatal cases liver tissue was obtained

TABLE III

Protein, DNA and RNA content of the liver *

\begin{tabular}{|c|c|c|c|c|c|c|c|}
\hline \multirow[b]{2}{*}{ Time of biopsy } & \multirow{2}{*}{$\begin{array}{l}\text { Number of } \\
\text { specimens }\end{array}$} & \multicolumn{3}{|c|}{ 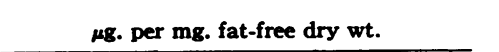 } & \multirow{2}{*}{$\frac{\text { Protein N }}{\underset{\mu g . / \mu g .}{\text { DNAP }}}$} & \multirow{2}{*}{$\begin{array}{l}\text { RNAP } \\
\text { DNAP } \\
\text { Mg./Mg. }\end{array}$} & \multirow{2}{*}{$\frac{\text { RNAP }}{\mathrm{Mg.} / \mathrm{mg} .}$} \\
\hline & & Protein N & DNAP & RNAP & & & \\
\hline (1) & (2) & (3) & (4) & (5) & (6) & $(7)$ & (8) \\
\hline $\begin{array}{l}\text { On admission } \\
\text { After 3-8 weeks } \\
\text { After 9-24 weeks }\end{array}$ & $\begin{array}{r}12 \\
11 \\
8\end{array}$ & $\begin{array}{l}80 \pm 20.6 \\
71 \pm 12.7 \\
83 \pm 25.4\end{array}$ & $\begin{array}{l}1.73 \pm 0.53 \\
1.15 \pm 0.39 \\
1.12 \pm 0.30\end{array}$ & $\begin{array}{l}1.96 \pm 0.93 \dagger \\
1.59 \pm 0.45 \\
1.40 \pm 0.14\end{array}$ & $\begin{array}{l}49 \pm 15.9 \\
69 \pm 16.7 \\
83 \pm 28.8\end{array}$ & $\begin{array}{l}1.15 \pm 0.41 \\
1.53 \pm 0.39 \\
1.37 \pm 0.29\end{array}$ & $\begin{array}{l}0.25 \pm 0.11 \\
0.22 \pm 0.06 \\
0.17 \pm 0.06\end{array}$ \\
\hline
\end{tabular}

* Figures are mean \pm standard deviation.

$\dagger$ If one very high figure (RNAP $=4.60 \mu \mathrm{g}$. per mg.) is omitted, this becomes $1.71 \pm 0.53$. 
by the usual puncture technique within 30 minutes of death. In one other baby included in this group a biopsy was done one day before death. It had been expected that in these fatal cases both N/DNA-P and RNA-P/DNA-P would be low, but this was not found. The results in these seven cases were as follows :

N/DNA-P: $(\mu \mathrm{g} . / \mu \mathrm{g}$.$) \quad mean 63.0$ range $43-95$

RNA-P/DNA-P: ( $\mu \mathrm{g} . / \mu \mathrm{g}$.) mean 1.86 range $1.13-2.44$

It was particularly unexpected to find that RNA$\mathrm{P} / \mathrm{DNA}-\mathrm{P}$ was on the average higher even than in the livers of treated cases. Some specimens taken at autopsy one or more days after death have shown similarly high figures.

These results could be explained if there had been a loss of DNA from the liver. According to Leuchtenberger, Leuchtenberger, and Davis (28), post-mortem change should not produce significant effects in such a short time. It is possible that some destruction of DNA may have occurred before death, such as is known to occur when there is pyknosis of the nucleus (Leuchtenberger [29]). This, however, is only a suggestion for which we have no evidence. The microscope does not give us much information on this point, because the nucleus tends to be distorted by the accumulation of fat in the cell. This point is being investigated.

\section{DISCUSSION}

The validity of using DNA as a standard of reference for other measurements has been discussed in detail by Davidson and his colleagues (Thomson, Heagy, Hutchison, and Davidson [9]). They confirmed and extended the earlier observations of Campbell and Kosterlitz (7), that in the adult rat the amount of DNA per cell and per liver is constant over a wide range of dietary conditions. In the growing animal the position is less clear. In man during growth there is an increase in the proportion of large, presumably polyploid nuclei (Böhm [30]). In the rat several authors have found an increase in the average amount of DNA per nucleus (Thomson, Heagy, Hutchison, and Davidson [9] ; Fukuda and Sibatani [31]; Jacob, Mandel, and Mandel [32]).

During growth there is also a great increase in the total number of liver cells. The joint effect of these two processes-multiplication of cells and increase in DNA per cell-is that the total liver DNA rises roughly pari passu with body weight (Campbell and Kosterlitz [7] ; Jacob, Mandel, and Mandel [32]). Of these two processes the former is quantitatively far more important. The data of Jacob, Mandel, and Mandel (32) show that in rats between the ages of 8 and 60 days the total liver DNA increased 12 times; the average amount of DNA per nucleus increased only by a factor of 1.3 , so that there must have been a 9 -fold increase in the number of cells.

Little is known about the effect of malnutrition on these two processes. Ely and Ross (33) found an increased DNA content per nucleus, compared with controls, in young rats kept for periods of up to 7 weeks on a protein-free diet. Fukuda and Sibatani (31) showed that when young rats were put on a restricted diet so that they no longer gained weight, the amount of DNA per liver cell nucleus still continued to increase in the normal way. Thus the DNA per cell seemed to depend on the age or the ideal weight of the rat, and not on its actual body weight.

In neither of these papers are figures given for liver weights, from which it would be possible to calculate the total liver DNA or to estimate the number of cells. Histological observations suggest that malnutrition slows down the multiplication of liver cells. Balfour (34) found that when young rats are given an adequate diet after a period on a ration low in protein (cassava) there is a burst of mitotic activity in the liver. This fits in with the suggestion of Thomson, Heagy, Hutchison, and Davidson (9), in discussing the work of Ely and Ross (33), that protein deficiency might inhibit growth and mitosis to a greater extent than it affects the premitotic synthesis of DNA.

It is therefore difficult to assess from the experimental work the probable effect on liver DNA in our human cases of a period of malnutrition followed by a period of treatment with a good diet. It seems reasonable to suppose that during treatment the amount of DNA per cell either remained the same or increased slightly. Histologically, in biopsies taken after one month or more of treatment, large, probably polyploid. nuclei seemed to be more numerous than in the initial biopsies. This suggests that there may well have been some 
increase in the average $\mathrm{DN} \dot{A}$ content per nucleus, which would tend to mask simultaneous increases in protein and RNA. It would be desirable to check this point, either by spectrophotometric measurements by the method of Pollister (35), or by making nuclear counts, and relating them to the total DNA content of the specimen. Work on these lines is proceeding. In any case. however, an increase in DNA content per nucleus would not invalidate the conclusions that have been drawn. On the contrary, the differences that have been found between the first and subsequent biopsies in the ratios of RNA and protein to DNA would become all the more significant.

It is also probable that during treatment there was an increase in the total number of liver cells. No excess of mitoses was observed, but the increase in number of polyploid nuclei is usually regarded as evidence of regeneration and multiplication of cells. It is therefore likely that the increase in total liver protein was even greater than is shown by the figures for protein/DNA.

A further complication is the fact that the liver is by no means a homogeneous tissue. A few cellcounts that were done on infant livers in Africa (Walters and Waterlow [26]) showed that in the most normal livers available only two-thirds of the cells were hepatic cells. From a comparative point of view it would not affect the results if the proportion of hepatic and non-hepatic cells were constant. No actual counts have been made in the livers of this series, but histological examination gives the impression that there is a slight cellular infiltration in the specimens taken after treatment. These infiltrating cells probably contain less cytoplasmic protein and RNA per unit DNA than the hepatic cells proper; therefore an error introduced in this way would work in the same direction as the error caused by an increase in DNA content per nucleus, and the differences that have been found between specimens before and after treatment would again tend to be under-estimates rather than over-estimates.

There is a third factor which influences the interpretation of these results. When an animal is put on a protein-free diet its liver loses a large proportion of its protein, but this loss does not increase progressively with time. For instance, Campbell and Kosterlitz (36) found that the reduction in liver nitrogen on a protein-free diet was no greater after 7 days than after 4 days. This is in keeping with the fact that the liver has a much more rapid turnover of protein than the so-called carcass (Sprinson and Rittenberg [37]). Muscle loses its protein more slowly than the liver (Addis, Poo, and Lew [38] ), and presumably goes on doing so for a longer time. Thus the liver of a child which has been on a protein-deficient diet for 3 months will not necessarily be more depleted than the liver of one who has been on the same diet for one month.

It had originally been our hope that these measurements made on the liver might provide some index of the severity of protein depletion. Although they are not suitable for routine use, they might still provide a baseline for other and simpler measurements. The results suggest that useful statistical information can be obtained about a group of cases, but that a single measurement is of little value as a guide to the severity of an individual case. Even with an increase in the precision of the methods, it seems unlikely that this objective can be achieved, because of the sampling error and of the other sources of variability that have been discussed. Nevertheless, it is possible that an extension of these measurements to a wider variety of cases, and to other tissues, such as muscle, might give further insight into the type and degree of protein depletion produced by various forms of dietary deficiency.

\section{SUMMARY}

1. Measurements made on biopsy specimens of the liver from a selected group of severely malnourished infants show a great excess of fat, a slight and doubtful increase in water content, and a high concentration of glycogen.

2. The protein and ribosenucleic acid (RNA) contents of the biopsy specimens were measured and related to deoxyribosenucleic acid (DNA). These measurements were made soon after admission to hospital, and repeated after one to two months on a high protein diet.

3. On the assumption that the amount of DNA per cell and per liver remains constant, the results show that at the time of admission these cases had on the average lost some 40 per cent of their liver protein and RNA.

4. Evidence is discussed suggesting that the assumption of a constant DNA content is not 
valid in this material. However, the errors introduced by this assumption tend to decrease, rather than to exaggerate, the differences found between biopsies before and after treatment.

5. It is concluded that measurements of this type may give useful statistical information about a group of cases, but they are not precise enough to serve as an index of the degree of protein depletion in a single case at a single moment of time.

\section{ACKNOWLEDGMENTS}

We are deeply indebted to Professor E. K. Cruickshank for putting beds at our disposal in the pediatric ward of the University College Hospital of the West Indies, to Dr. K. Lamont Stuart, who performed most of the biopsies, and to Dr. G. Bras, who examined the histological sections.

\section{REFERENCES}

1. Gillman, J., and Gillman, T., Perspectives in Human Malnutrition. A Contribution to the Biology of Disease from a Clinical and Pathological Study of Chronic Malnutrition and Pellagra in the African. New York, Grune \& Stratton, 1951.

2. Waterlow, J. C., Fatty liver disease in infants in the British West Indies, London, H.M.S.O., 1948, Med. Res. Counc. Gt. Brit. Spec. Rep Ser. no. 263.

3. Trowell, H. C., Davies, J. N. P., and Dean, R. F. A., Kwashiorkor. London, Arnold, 1954.

4. Waterlow, J. C., in Protein Malnutrition, J. C., Waterlow, Ed., Rome, Food and Agriculture Organization of the United Nations, 1955, p. 16.

5. Addis, T., Poo, L. J., and Lew, W., Protein loss from liver during a two day fast. J. Biol. Chem., 1936, $115,117$.

6. Kosterlitz, H. W., The effects of changes in dietary protein on the composition and structure of the liver cell. J. Physiol., 1947, 106, 194.

7. Campbell, R. M., and Kosterlitz, H. W., The effects of growth and sex on the composition of the liver cells of the rat. J. Endocrinol., 1950, 6, 308.

8. Munro, H. N., and Naismith, D. J., The influence of energy intake on protein metabolism. Biochem. J., 1953, 54, 191.

9. Thomson, R. Y., Heagy, F. C., Hutchison, W. C., and Davidson, J. N., The deoxyribonucleic acid content of the rat cell nucleus and its use in expressing the results of tissue analysis, with particular reference to the composition of liver tissue. Biochem. J., 1953, 53, 460.

10. Waterlow, J. C., Observations on the activity of some enzymes in the human liver. W. I. med. J., 1951, $1,41$.

11. Waterlow, J. C., Enzyme activity in human liver in Trans. 11th Conf. on Liver Injury, F. W. Hoffbauer, Ed., New York, Josiah Macy Jr. Foundation, 1952, p. 72.
12. Waterlow, J. C., and Patrick, S. J., Enzyme activity in fatty livers in human infants. Ann. New York Acad. Sc., 1954, 57, 750.

13. Iversen, $P$., and Roholm, K., On aspiration biopsy of liver, with remarks on its diagnostic significance. Acta med. Scandinav., 1939, 102, 1.

14. Billing, B. H., Conlon, H: J., Hein, D. E., and Schiff, L., The value of needle biopsy in the chemical estimation of liver lipids in man. J. Clin. Invest., 1953, 32, 214.

15. Schneider, W. C., Phosphorus compounds in animal tissues. I. Extraction and estimation of desoxypentose nucleic acid and of pentose nucleic acid. J. Biol. Chem., 1945, 161, 293.

16. Steele, R., Sfortunato, T., and Ottolenghi, L., A micromethod for the determination of the nucleic acids. J. Biol. Chem., 1949, 177, 231.

17. Ceriotti, G., A microchemical determination of desoxyribonucleic acid. J. Biol. Chem., 1952, 198, 297.

18. Ogur, M., and Rosen, G., The nucleic acids of plant tissues. I. The extraction and estimation of desoxypentose nucleic acid and pentose nucleic acid. Arch. Biochem., 1950, 25, 262.

19. Brues, A. M., Tracy, M. M., and Cohn, W. E., Nucleic acids of rat liver and hepatoma: their metabolic turnover in relation to growth. J. Biol. Chem., 1944, 155, 619.

20. Mejbaum, W., Úber die Bestimmung kleiner Pentosemengen, insbesondere in Derivaten der Adenylsaüre. Ztschr. f. physiol. Chem., 1939, 258, 117.

21. Drury, H. F., Identification and estimation of pentoses in the presence of glucose. Arch. Biochem., 1948, 19, 455.

22. Johnson, M. J., Isolation and properties of a pure yeast polypeptidase. J. Biol. Chem., 1941, 137, 575.

23. Patrick, S. J., Effect of hypoglycin A on liver glycogen with a method for the study of changes in liver glycogen. J. Applied Physiol., 1954, 7, 140.

24. Jelliffe, D. B., Bras, G., and Stuart, K. L., Kwashiorkor and marasmus in Jamaican infants. W. I. med. J., 1954, 3, 43.

25. Dean, R. F. A., and Schwartz, R., The serum chemistry in uncomplicated kwashiorkor. Brit. J. Nutr., 1953, 7, 131.

26. Walters, J. H., and Waterlow, J. C., Fibrosis of the Liver in West African Children. London, H. M. S. O., 1954, Med. Res. Counc. Spec. Rep. Ser. no. 285.

27. Jelliffe, D. B., and Stuart, K. L., Acute toxic hypoglycaemia in the vomiting sickness of Jamaica. Brit. M. J., 1954, 1, 75.

28. Leuchtenberger, C., Leuchtenberger, R., and Davis, A. M., A microspectrophotometric study of the desoxyribose nucleic acid (DNA) content in cells of normal and malignant human tissues. Am. J. Path., 1954, 30, 65.

29. Leuchtenberger, C., A cytochemical study of pycnotic nuclear degeneration. Chromosoma, 1950, 3, 449. 
30. Böhm, J., quoted by Pfühl, W., in von Moellendorf's Handbuch der mikroskopische Anatomie des Menschen. Berlin, J. Springer, 1932, vol. 5, Part II.

31. Fukuda, M., and Sibatani, A., Relation between the body weight and the average DNA content of liver nuclei in postnatal growth of the rat. Exper. Cell. Res., 1953, 4, 236.

32. Jacob, M., Mandel, L., and Mandel, P., Etude de la consommation d'oxygène et de la teneur en acide désoxyribonucléique du foie à divers âges chez le rat. Experientia, 1954, 10, 218.

33. Ely, J. O., and Ross, M. H., Desoxyribonucleic acid content of rat liver nuclei influenced by diet. Science, 1951, 114, 70.

34. Balfour, B. M., Personal Communication, 1954.
35. Pollister, A. W., Microspectrophotometry of fixed cells by visible light. Lab. Invest., 1952, 1, 231.

36. Campbell, R. M., and Kosterlitz, H. W., The relationship between losses in labile liver cytoplasm and urinary nitrogen excretion. Biochem. J., 1948, 43, 416.

37. Sprinson, D. B., and Rittenberg, D., The rate of interaction of the amino acids of the diet with the tissue proteins. J. Biol. Chem., 1949, 180, 715.

38. Addis, T., Poo, L. J., and Lew, W., The quantities of protein lost by the various organs and tissues of the body during a fast. J. Biol. Chem., 1936, 115, 111.

39. Holt, L. E., and Howland, J., Holt's Diseases of Infancy and Childhood. Rev. by L. E. Holt, Jr., and R. McIntosh, 11th ed., New York, Appleton, 1941. 